\title{
OCCURRENCE OF ADHESIN-ENCODING OPERONS IN ESCHERICHIA COLI ISOLATED FROM BREEDERS WITH SALPINGITIS AND CHICKS WITH OMPHALITIS
}

\author{
Terezinha Knöbl ${ }^{1}$; Tânia A. Tardelli Gomes²; Mônica A. Midolli Vieira² ; José A. Bottino³ \\ Antonio J. Piantino Ferreira ${ }^{3 *}$
}

${ }^{1}$ Faculdade de Medicina Veterinária, Faculdades Metropolitanas Unidas, São Paulo, SP, Brasil; ${ }^{2}$ Departamento de Microbiologia, Imunologia e Parasitologia, Escola Paulista de Medicina, Universidade Federal de São Paulo, São Paulo, SP, Brasil; ${ }^{3}$ Departamento de Patologia, Faculdade de Medicina Veterinária e Zootecnia, Universidade de São Paulo, São Paulo, SP, Brasil

Submitted: July 25, 2005; Returned to authors for corrections: November 11, 2005; Approved: February 26, 2006

\begin{abstract}
The occurrence of fim, pap and sfa operons in Escherichia coli isolated from breeders with salpingitis and chicks with omphalitis was evaluated. Analysis of $100 \mathrm{E}$. coli isolates, by colony hybridization tests, showed that $78(78 \%)$ were $\mathrm{fim}^{+}$, one (1\%) was $s \mathrm{fa}^{+}$, seven (7\%) were $\mathrm{fim}^{+}$associated with $\mathrm{pap}^{+}$, eigth $(8 \%)$ were $\mathrm{fim}^{+}$ and $s f a^{+}$, one (1\%) was $\mathrm{fim}^{+} \mathrm{pap}^{+} s \mathrm{fa}^{+}$and five (5\%) isolates did not hybridize with any probe. These results suggest that fim adhesion-encoding operon plays an important role in pathogenesis of E. coli infection in chickens with salpingitis and omphalitis.
\end{abstract}

Key words: Escherichia coli, adhesion-encoding operon, salpingitis, omphalitis, poultry

\section{INTRODUCTION}

Pathogenic Escherichia coli can be isolated from a variety of well-defined conditions that occur in poultry: airsacculitis, chronic respiratory disease (CRD), salpingitis, omphalitis, peritonitis, swollen head syndrome (SHS), colisepticemia, synovitis, cellulitis and coligranuloma $(2,21)$. The agent is regarded as one of the principal causes of morbidity and mortality in poultry and is a leading cause of worldwide economic losses in the poultry industry, including that of Brazil.

Salpingitis is characterized by a subacute suppurative process compromising the oviduct, embryo development and day-old chick livability. In adult female birds, E. coli can infect the reproductive tract by resulting in salpingitis, oophoritis and peritonitis inducing chicken to death. Early infection in breeders may be clinically asymptomatic; occasionally it can be responsible for ensuing increase in embryonic mortality in the hatchery $(2,21)$.

Omphalitis, generally, is an infection that affects chicks during the hatching phase. Disease is an inflammation of the umbilicus and affected birds are envolved in culling in the first week of age and death. Usually, fecal contamination of eggs or salpingitis is considered the most important source of infection. Both infections are close related and the virulence factors remain unclear $(2,21)$.

The ability of bacteria to adhere to host epithelial cells is considered to be a prerequisite for the establishment of infectious diseases, mainly through expression of fimbriae $(3,22,24)$. Avian pathogenic E. coli (APEC) generally possess type 1 and $P$ fimbriae $(12,16,26,29)$.

Type 1 fimbriae are characterized by the ability to agglutinate chicken and guinea pig erythrocytes in the absence of Dmannose. They consist of a major protein, FimA, associated with ancillary proteins, FimF, FimG and the adhesin FimH, encoded by the fim gene cluster $(18,25)$. This type of fimbria is common among Enterobacteriaceae and several variants have been associated with APEC $(4,6,28,36)$. Their role in infection is unclear, although it has been suggested that they may be involved in the initial stages of colonization of upper respiratory $\operatorname{tract}(6,7,11,16,31)$. *Corresponding Author. Mailing address: Departamento de Patologia, Faculdade de Medicina Veterinária e Zootecnia, Universidade de São Paulo,
Av. Prof. Dr. Orlando M. Paiva, 87, Cidade Universitária. 05508-900, São Paulo, SP, Brasil. E-mail: af.piantino@ fmvz.usp.br 
P fimbriae are associated with pyelonephritis in humans and are encoded by the pap operon $(15,23)$. The role of $\mathrm{P}$ adhesins in APEC has not yet been fully elucidated, but they appear to be involved in the colonization of internal organs $(26,30)$.

The $\mathrm{S}$ fimbriae are mannose-resistant adhesins (MRHA), encoded by the $s f a$ operon, that recognizes $\alpha$-sialyl- $\beta-2,3-$ Galactose receptors, present on human and calf erythrocytes $(8,12)$. The presence of $\mathrm{S}$ fimbriae correlates with pathogenicity of $E$. coli in human meningitis and septicemia $(8,12,29)$. The role of S fimbriae in the pathogenicity of APEC remains unclear.

The purpose of this survey was to compare the occurrence of fim, pap and sfa genes in Escherichia coli isolated from breeders with salpingitis and from chicks with omphalitis.

\section{MATERIALS AND METHODS}

\section{Bacterial strains and growth conditions}

A total 100 isolates of $E$. coli were isolated from poultry in the São Paulo State of Brazil. The isolates were obtained from: (i) oviducts of broiler breeders with salpingitis $(n=50)$ and (ii) yolk sacs of day-old chicks with omphalitis $(n=50)$; Standard bacteriological methods were employed for isolation and identification of the organisms (2). All isolates were stored at $-20^{\circ} \mathrm{C}$ in Brain Heart Infusion (BHI) broth (Difco Laboratories, Detroit, MI, USA) to which $15 \%$ glycerol was added after incubation.

\section{Colony hybridization}

The test isolates were examined by colony blot hybridization (20), using specific DNA probes labeled with [ $\left.\alpha-d-{ }^{32} \mathrm{P}\right]-\mathrm{dATP}$ by nick translation (20).

The DNA probe used to detect fim $\mathrm{B}-\mathrm{H}$ genes was a $9.6 \mathrm{~Kb}$ HindIII-SalI fragment from recombinant plasmid, pIB254 (17). Detection of pap and $s f a$ genes involved oligonucleotide fragments obtained by the polymerase chain reaction, as described by Le Bouguenec and coworkers (19). The prototype wild-type strains from which DNA probes are derived were used as positive controls of each probe. E. coli K12 C600/pBR322 was used as negative control in all hybridization tests.

\section{Statistical methods}

Differences between groups of isolates were tested by using the software "SPSS for Windows" version 9.0 (SPSS, Chicago, IL, USA), by Fisher's exact test, using $\mathrm{X}^{2}$ of Pearson, for lowvalue data. Differences were considered to be significant when $\mathrm{p}<0.05$.

\section{RESULTS}

Of the 100 E.coli isolates examined in both diseases, 78 $(78 \%)$ isolates hybridized with fim operon. Considering that 50 isolates were obtained from salpingitis and 50 from omphalitis, $43(86 \%)$ and $35(70 \%)$ hibridized with the probe for fimB-H detection, respectively. There were no significant differences between both groups in relation to the presence of fim gene $(P<0.05)$.

sfa operon was detected only in one $(2 \%)$ isolate from omphalitis. The association of fim and pap genes were detected in three $(6 \%)$ from salpingitis and four $(8 \%)$ from omphalitis. When the association between fim and $s f a$ was considered, only one (2\%) and seven (14\%) hybridized with these probes in salpingitis and omphalitis, respectively. There were significant differences regarding the presence of these operons in $E$. coli isolates from breeders with salpingitis and chicks with omphalitis $(P<0.05)$. Detection of combination of three operons was observed only in one (2\%) isolate from salpingitis. Two (4\%) isolates from salpingitis and three $(6 \%)$ from omphalitis groups did not hybridize with any probe employed. The comparisons of all results are shown in the Table 1.

Table 1. Distribution of fim, pap and sfa-related nucleotide sequences among avian Escherichia coli isolates.

\begin{tabular}{cccc}
\hline Genotype pattern & \multicolumn{3}{c}{$\begin{array}{c}\text { Number of probe-positive } \\
\text { isolates (\%) from }\end{array}$} \\
\cline { 2 - 4 } & Salpingitis & Omphalitis & Total \\
\hline fim $^{+}$ & $43(86)$ & $35(70)$ & $78(78)$ \\
sfa $^{+}$ & $0(0)$ & $1(2)$ & $1(1)$ \\
fim $^{+}$pap $^{+}$ & $3(6)$ & $4(8)$ & $7(7)$ \\
fim $^{+}$sfa $^{+}$ & $1(2)$ & $7(14)$ & $8(8)$ \\
fim $^{+}$pap $^{+}$sfa & $1(2)$ & $0(0)$ & $1(1)$ \\
None* & $2(4)$ & $3(6)$ & $5(5)$ \\
\hline Total & 50 & 50 & 100 \\
\hline
\end{tabular}

* None of these isolates hybridized with fim, pap or sfa operon probe.

\section{DISCUSSION}

Certain genotypic traits associated with $E$. coli causing extraintestinal disease in humans are frequently found in APEC. Epidemiological investigations have shown a good correlation between the occurrence of certain human diseases and the presence of specific virulence factors in E. coli $(1,5,33)$. Operons encoding $\mathrm{P}, \mathrm{S}$ and Afa adhesins, production of $\alpha$-haemolysin and cytotoxic necrotizing factor type 1 (CNF1) contribute to the pathophysiology of urinary tract infections, while genes encoding for S fimbriae, K1 capsule and Ibe 10 protein are correlated with the pathogenesis of neonatal meningitis $(13,14)$.

APEC can be responsible for many localized and systemic diseases in poultry, but the pathophysiology of these infections remains unclear. In the present study it has been shown that 
the presence of pap and $s f a$ operons varies among strains associated with different diseases. Table 1 shows, also, that pap, sfa or any operon combination were detected with a lower frequency in salpingitis and omphalitis. By the other hand, fim operon was detected with a higher frequency in two groups, $70 \%$ from the omphalitis and $86 \%$ from the salpingitis isolates.

This study also confirms previous observations that mannose-sensitive adhesins are frequently present in APEC and type 1 fimbriae may play a role in tracheal colonization $(6,9,10,11,31,32,34,35)$. Pourbakhsh and coworkers (26) investigated the site of in vivo expression of type 1 and $\mathrm{P}$ fimbriae in experimentally inoculated chickens and suggested that type 1 fimbriae are involved in the initial stages of bacterial colonization of the upper respiratory tract, whereas P fimbriae may be involved in the colonization of internal organs and in the development of septicemia, although this fimbria was not detected with a high frequency in this survey. There is no enough information in the literature to establish a correlation between the presence of type 1 fimbriae in APEC with penetration of mucus and ascending contamination of the vagina, following cloacal colonization in breeder chickens. Nevertheless, such association is likely.

The S fimbriae are able to promote the adherence of $E$. coli to endothelial and epithelial cells of the coroid plexus and cerebral ventriculus in man (27). This type of fimbria was rarely detected in APEC and its role in the pathogenesis of avian colibacillosis is presently unclear. It is possible that bacterium with S fimbriae is from human origin and that chicks become infected due to poor hygiene during handling of eggs in the hatchery. Experimental infection will be useful for gaining an understanding the role of fimbrial expression and the mechanisms of adhesion to specific tissues.

A continous surveillance study should be introduced to assess the importance of type 1 fimbriae in the pathogenesis of avian colibacillosis regarding salpingitis and omphalitis infection for to implement an immunization program.

\section{ACKNOWLEDGMENTS}

We are grateful to FAPESP (Fundação de Amparo à Pesquisa do Estado de São Paulo) for financial support - Grant $n^{\circ}$ 97/ 03250-3.

\section{RESUMO}

\section{Ocorrência de operons codificadores de adesinas em Escherichia coli isolada de aves reprodutoras com salpingite e de pintinhos com onfalite}

Ocorrência dos operons fim, pap e sfa em amostras de Escherichia coli isoladas de reprodutoras com salpingite e pintinhos com onfalite foi avaliada. A análise de 100 amostras através dos testes de hibridização de colônia mostrou que 78 (78\%) amostras eram $\mathrm{fim}^{+}$, uma (1\%) era $s f a^{+}$, sete (7\%) eram fim $^{+}$associada a pap $^{+}$, oito (8\%) eram fim $^{+}$e uma (1\%) era fim $^{+}$pap $^{+} \mathrm{Sfa}^{+}$e cinco $(5 \%)$ amostras não hibridizaram com nenhuma sonda. Estes resultados sugerem que o operon fim pode ter um importante papel na patogenia da infecção de Escherichia coli em reprodutoras com salpingite e pintinhos com onfalite.

Palavras-chave: Escherichia coli, operon codificador de adesina, genes, salpingite, onfalite, aves

\section{REFERENCES}

1. Archambaud, M.; Courcox, P.; Ouin, V.; Chabanon, G.; LabigneRoussel, A. Phenotypic and genotypic assays for the detection and identification of adhesins from pyelonephritic Escherichia coli. Ann. Microbiol., 139, 557-573, 1988.

2. Barnes, J.H.; Gross, W.B. Colibacillosis. In: Calnek, B.W.; Barnes, J.H.; Beard, C.W.; Mac Dougald, R.L.; Saif, Y.M. (eds.). Diseases of Poultry. Iowa State University Press, Ames, Iowa, 1997, p.131-141.

3. Beachey, E.H. Bacterial adherence: adhesin-receptor interactions mediating the attachment of bacteria to mucosal surfaces. J. Infect. Dis., 143, 325-345, 1981.

4. Chanteloup, N.K.; Dho-Moulin, M.; Esnault, E.; Bree, A.; Lafont, J.P. Serological conservation and location of the adhesin of avian Escherichia coli Type I fimbriae. Microb. Pathog., 10, 271-280, 1991.

5. Dalet, F.; Segovia, T.; Del Rio, G. Frequency and distribuition of uropathogenic Escherichia coli adhesins: a clinical correlation over 2,000 cases. Eur. Urol., 19, 295-303, 1991.

6. Dho, M.; Bosch, F.; Girardeau, J.P.; Brée, A.; Barat, T.; Lafont, J.P. Surface antigens from Escherichia coli $\mathrm{O} 2$ and $\mathrm{O} 78$ strains of avian origin. Infect. Immun., 58, 740-745, 1990.

7. Dho, M.; Lafont, J.P. Escherichia coli colonization of the trachea in poultry: comparasion of virulent and avirulent strains in gnotoxenic chickens. Avian Dis., 26, 787-797, 1992.

8. Donnenberg, M.S.; Welch, R.A. Virulence determinants in uropathogenic Escherichia coli. In: Mobley, H.L.T.; Warren, J.W. (eds). Urinary tract infections: Molecular Pathogenesis and Clinical Management, ASM Press, Washington, DC, 1996, p.135-174.

9. Dozois, C.M.; Chanteloup, N.; Dho-Moulin, M.; Brée, A.; Desaultels, C.; Fairbrother, J.M. Bacterial colonization and in vivo expression of F1 (type 1) fimbrial antigens in chickens experimentally infected with pathogenic Escherichia coli. Avian Dis., 38, 231-239, 1994.

10. Dozois, C.M.; Fairbrother, J.M.; Harel, J.; Bossé, M. pap-and pilrelated DNA sequences and other virulence determinants associated with Escherichia coli isolated from septicemic chickens and turkeys. Infect. Immun., 60, 2648-2656, 1992.

11. Gyimah, J.E.; Panigrahy, B. Adhesin-receptor interations mediating the attachment of pathogenic Escherichia coli to chicken tracheal epithelium. Avian Dis., 32, 74-78, 1988.

12. Hacker, J.; Morschhäuser, J. S and F1C Fimbriae. In: Klemm, P. (ed). Fimbriae: adhesion, genetics, biogenesis and vaccines. CRC Press, Copenhagen, 1994, p.27-36.

13. Huang, S.H.; Wass, Q.F.; Prasadarao, N.V.; Stins, M.; Kim, K.S. Escherichia coli invasion of brain microvascular endothelial cells in vitro and in vivo: molecular cloning and characterization of invasion gene ibe10. Infec. Immun. 63, 4470-4475, 1995.

14. Hughes, C.; Hacker, J.; Roberts, A.; Goebel, W. Hemolysin production as a virulence marker in symptomatic and assymptomatic urinary 
tract infections caused by Escherichia coli. Infect. Immun., 39, 546$551,1983$.

15. Hull, R.A.; Gill, R.E.; Hsu, P.; Minishew, B.H.; Falkow, S. Construction and expression of recombinant plasmids encoding type 1 or Dmannose resistant pili from a urinary tract infection Escherichia coli. Infect. Immun., 33, 933-938, 1981.

16. Ike, K.; Kume, K.; Kawahara, K.; Danbara, H. Serotyping of O and pilus antigens of Escherichia coli strains isolated from chickens with colisepticemia. Jpn. J. Vet. Sci., 52, 1023-1027, 1990.

17. Klemm, P.; Christiansen, G. Three fim genes required for the regulation of length and mediation of adhesion of Escherichia coli type 1 fimbriae. Mol. Gen. Genet., 208, 439-445, 1987.

18. Klemm, P.; Krogfelt, K.A. Type 1 fimbriae of Escherichia coli. In: Klemm, P. (ed.). Fimbriae: adhesion, genetics, biogenesis, and vaccines. CRC Press, Copenhagen, 1994, p.9-25.

19. Le Bouguenec, C.L.; Archambaud, M.; Labigne, A. Rapid and specific detection of the pap, afa and $s f a$ adhesin-encoding operons in uropathogenic Escherichia coli strains by polymerase chain reaction. J. Clin. Microbiol., 30, 1189-1193, 1992.

20. Maas, R. An improved colony hybridization method with significantly increased sensitivity for detection of single genes. Plasmid, 10, 296-298, 1983.

21. Monroy, M.A.R.; Knöbl, T.; Bottino, J.A.; Ferreira, C.S.A.; Ferreira, A.J.P. Virulence characteristics of Escherichia coli isolates obtained from broiler breeders with salpingitis. Comp. Immun. Microbiol. Infect. Dis., 28, 1-15, 2005.

22. Naveh, M.W.; Zusman, T.; Skutelsky, E.; Ron, E.Z. Adherence pili in avian strains of Escherichia coli: effect on pathogenicity. Avian Dis., 25, 651-661, 1984.

23. Normark, S.; Lark, D.; Hull, R.; Norgren, M.; Braga, M.O.; Hanley, P.; Schoolnik, G.; Falkow, S. Genetics of digalactoside-binding from a uropathogenic Escherichia coli strain. Infect. Immun., 41, 942 949, 1983

24. Ofek, I.; Doyle, R.J. Regulation and expression of bacterial adhesins. In: Ofek, I.; Doyle, R.J. (eds.). Bacterial adhesion to cells and tissues. Chapman \& Hall, New York, 1993, p.239-320.

25. Orndorff, P.E.; Falkow, S. Organization and expression of genes responsible for type 1 piliation in Escherichia coli. J. Bacteriol., 159, 736-744, 1994.
26. Pourbakhsh, S.A.; Dho-Moulin, M.; Brée, A.; Desautels, C.; MartineauDoizé, B.; Fairbrother, J.M. Localization of the in vivo expression of $\mathrm{P}$ and $\mathrm{F} 1$ fimbriae in chickens experimentally inoculated with pathogenic Escherichia coli. Microb. Pathog., 22, 331-341, 1997.

27. Prasadarao, N.V.; Stins, M.F.; Wass, C.A.; Kin, K.S. Role of $S$ fimbriae and outer membrane protein A in Escherichia coli binding to and invasion of endothelial cells. Proceedings of Annual Meeting for Experimental Biology. Abstracts, 1994, p.A70.

28. Sekizaki, T.; Miyazaki, S.; Ito, H.; Asawa, T.; Nonomura, I. Isolation and characterization of type I fimbriae from chicken pathogenic Escherichia coli serotype O78. J. Vet. Med. Sci., 54, 1145-1149, 1992.

29. Smyth, C.J.; Marron, M.; Smith, S.G.J. Fimbriae of Escherichia coli. In: Gyles, C.L. (ed.). Escherichia coli in Domestic animals and man. CAB International, Oxford, 1995, p.399-435.

30. Strömberg, N.; Marklund, B.I.; Lund, B.; Ilver, D.; Amers, A.; Gaastra, W.; Karlsonn, K.A.; Normark, S. Host-specificity of uropathogenic Escherichia coli depends on difference in binding specificity to Gala-1-4-b-Gal containing receptors. EMBO J., 9, 2001-2010, 1990.

31. Suwanichkul, A.; Panigrahy, B. Biological and immunological characterization of pili of Escherichia coli serotypes O1, O2, and O78 pathogenic to poultry. Avian Dis., 30, 781-787, 1986.

32. Suwanichkul, A.; Panigrahy, B.; Wagner, R.M. Antigenic relatedness and partial amino acid sequences of pili of Escherichia coli serotypes O1, O2, and O78 pathogenic to poultry. Avian Dis., 31, 809-813, 1987.

33. Tomisawa, S.; Kogure, T.; Kuroume, T.; Leffler, H.; Lomberg, H.; Shimabukoro, N.; Terao, K.; Svanborg Eden, C. P blood group and proneness to urinary tract infection in Japanese children. Scand. J. Infect. Dis., 21, 403-408. 1989.

34. Vidotto, M.C.; Navarro, H.R.; Gaziri, L.C.J. Adherence pili of pathogenic strains of avian Escherichia coli. Vet. Microbiol., 59, 7987, 1997.

35. Wooley, R.E.; Spears, K.R.; Brown, J.; Nolan, L.K.; Fletcher, O.J. Relationship of complement resistance and selected virulence factors in pathogenic avian Escherichia coli. Avian Dis., 36, 679-684, 1992.

36. Yerushalmi, Z.; Smorodiinsky, N.I.; Naveh, M.W.; Ron, E.Z. Adherence pili of avian strains of Escherichia coli O78. Infect. Immun., 58, 1129-113, 1990 